\title{
Marine habitat use of wintering spectacled petrels Procellaria conspicillata, and overlap with longline fishery
}

\author{
Leandro Bugoni ${ }^{1,2, *}$, Liliana D'Alba ${ }^{1}$, Robert W. Furness ${ }^{1}$ \\ ${ }^{1}$ Institute of Biomedical and Life Sciences, University of Glasgow, Glasgow G12 8QQ, UK \\ ${ }^{2}$ Projeto Albatroz, Av. dos Bancários, 76/22, Ponta da Praia, CEP 11.030-300, Santos, SP, Brazil
}

\begin{abstract}
Satellite transmitters were used to determine the marine habitat utilization and fishery overlap of wintering spectacled petrels Procellaria conspicillata in the southwestern Atlantic Ocean in 2006 and 2007. Kernel density analysis of tracked birds demonstrated intense use of waters in the Brazilian Exclusive Economic Zone, from 26 to $31^{\circ} \mathrm{S}$, mainly over the continental shelf break and offshore waters (mean depth in the $<20 \%$ kernel density areas $=1043 \pm 794 \mathrm{~m}$ ), over warm tropical and subtropical waters (mean SST $=22^{\circ} \mathrm{C}$ and $21^{\circ} \mathrm{C}$ in 2006 and 2007, respectively) and mesotrophic/ oligotrophic waters (chlorophyll a density $=0.301$ and $0.281 \mathrm{mg} \mathrm{m}^{-3}$ in 2006 and 2007, respectively). These habitats used by spectacled petrels are remarkably different from those used by their sister species, the white-chinned petrel $P$. aequinoctialis, which occurs mainly over the continental shelf on sub-Antarctic and productive waters. A close association between spectacled petrels and the pelagic longline fishery was demonstrated through comparison of the main kernel areas used by spectacled petrels and the areas used by the pelagic longline fleet determined by fishing effort at resolution of $1 \times 1^{\circ}$ quadrants. Travel speeds and distances during night and daytime periods did not differ. The present study demonstrates the importance of high resolution fishing effort data to address relationships between bird marine habitat use and specific fishing fleets, and to determine marine habitats and investigate at sea segregation between closely related species.
\end{abstract}

KEY WORDS: Procellariiformes $\cdot$ Foraging grounds $\cdot$ Procellaria conspicillata $\cdot$ Wintering $\cdot$ Longline fishery $\cdot$ Kernel habitat use

\section{INTRODUCTION}

Incidental captures in longline fisheries are the most important global threat to the survival of most albatross populations (Gales 1998), and also adversely affect several petrel species (Weimerskirch et al. 1999, BirdLife International 2004). The threats frequently occur far from breeding grounds because Procellariiformes travel thousands of kilometres to feed during breeding and wintering periods (Weimerskirch et al. 1999, Phillips et al. 2006). Since the development of satellite technologies for tracking birds during 1980s, a range of detailed information on movements of alba- trosses and petrels away from breeding colonies was generated. Further improvements in location accuracy and device miniaturization were achieved, and, more recently, bird-borne satellite transmitters have been applied in the context of conservation of these highly endangered species by determining the overlap of seabird distribution and fishing activities (e.g. Hyrenbach \& Dotson 2003, Cuthbert et al. 2005, Phillips et al. 2006), or the definition of appropriate marine protected areas for albatrosses and petrels (Awkerman et al. 2005, Terauds et al. 2006). For species with previous evidence of being affected by fisheries, determining seabird locations using remote sensors, such as satel- 
lite transmitters or geolocators, and the simultaneous analysis of the distribution of the fishing fleet is of increasing conservation relevance (Phillips et al. 2007). By using this approach a range of conservation measures could be delineated by focusing on particular fleets interacting with the species, establishing responsibilities to particular countries, and establishing of spatial or temporal closures to reduce bycatch rates. In the present study we tracked a threatened species, the spectacled petrel Procellaria conspicillata, on their wintering grounds in the southwestern Atlantic Ocean and described their habitat use in relation to oceanographic variables and distribution of the key fishing fleets.

The spectacled petrel was considered a subspecies of the white-chinned petrel Procellaria aequinoctialis until recently (Ryan 1998). It is endemic to Inaccessible Island, in the Tristan da Cunha Archipelago, with a global breeding population of 9000 pairs (Ryan et al. 2006), and is currently identified as 'vulnerable' to extinction (BirdLife International 2008). The species probably declined severely during 19th and early 20th century due to predation by feral pigs (Ryan 1998, Ryan et al. 2006). Population models indicate that the population is now at risk of extinction primarily due to incidental capture in longline fisheries (Ryan et al. 2006).

The at-sea distribution of spectacled petrels was initially described to be throughout the South Atlantic in a band from Africa to South America between 25 and $40^{\circ} \mathrm{S}$ (Enticott \& O'Connell 1985). However, it appears to be a regular, but scarce visitor off the African coast, with only 30 birds recorded in 2000 during 629 ten minute counts (Camphuysen \& van der Meer 2000). In the SW Atlantic Ocean, it is recorded from the Brazilian state of Bahia $\left(12^{\circ} \mathrm{S}\right.$, Lima et al. 2004) to the Falkland Islands (Islas Malvinas, ca. $52^{\circ} \mathrm{S}$ ), but is rare south of $40^{\circ} \mathrm{S}$ (Imberti 2002). Large concentrations occur in southern Brazil, where up to 300 birds (about $1.5 \%$ of the entire species' population) have been recorded following a single vessel (Neves et al. 2006a). In this region it is the most common pelagic seabird throughout the year in both continuous and snapshot censuses, with a strong tendency to follow longline fishing vessels (Olmos 1997, Neves et al. 2006b). It has been suggested that the species occurs preferentially over warm (Olmos 1997) and deep waters (Olmos \& Bugoni 2006).

The domestic Brazilian pelagic longline fleet is based at southern and southeastern ports and operates mainly in this area during winter and early spring months, targeting tuna, swordfish and sharks (Bugoni et al. 2008c). Considerable numbers of albatrosses and petrels are incidentally captured by the fleet, mostly black-browed Thalassarche melanophris and Atlantic yellow-nosed $T$. chlororhynchos albatrosses, and white-chinned and spectacled petrels (Neves et al. 2006b, Bugoni et al. 2008c). Despite spectacled petrels frequently attending longline vessels in higher numbers than the white-chinned petrel (Olmos 1997, Neves et al. 2006a) the latter has higher bycatch rates in the area (Jiménez \& Domingo 2007, Bugoni et al. 2008c). The reasons for differential capture rates among these similar sized and closely related species are unclear. Nocturnal foraging (unusual among most Procellariiformes) has been suggested as an important factor determining the incidental capture of whitechinned petrels in South Africa and Kerguelen (Barnes et al. 1997, Ryan \& Boix-Hinzen 1998, Weimerskirch et al. 2000), and setting hooks at night has been postulated as an effective mitigation measure to reduce bycatch of most seabirds (Cherel et al. 1996, Barnes et al. 1997). In the SW Atlantic, longline setting frequently takes place at night and this practice has been advocated as an effective measure for reducing incidental capture of albatrosses and most petrels (Neves et al. 2006b). The effectiveness of nocturnal setting for avoiding spectacled petrel bycatch remains to be determined. Seabird associations with fisheries could be both detrimental, by reducing prey species used by birds or incidental mortality, or beneficial in the short term by providing bait and discards otherwise unavailable to birds (Furness 2003). Whether spectacled petrels benefit by feeding extensively on fishery discards (Neves et al. 2006a) or are adversely affected by the bycatch mortality they experience in this fishery (Bugoni et al. 2008c) remains unclear. Improving knowledge of the ecology and behaviour of both spectacled and white-chinned petrels is crucial to understanding the differences in bycatch rates of these species, as well as our ability to propose effective mitigation measures to aid their conservation.

The pricipal threat facing the vulnerable spectacled petrel is longline fishery bycatch in the SW Atlantic Ocean, making this the key area for its conservation. In the present study we compare the marine habitats used by wintering spectacled petrels with fishing effort in quadrants of $1 \times 1^{\circ}$, thus providing a finescale comparison of habitat utilization by birds and fisheries over the same time period. We additionally investigated (1) relationships between the distribution of birds and oceanographic features such as sea surface temperature (SST), chlorophyll a ( $\mathrm{chl}$ a) and bathymetry; (2) the behaviour of birds during night and daytime periods as an indicator of foraging behaviour and potential interaction with the usual nocturnal setting of longline hooks; and (3) the segregation in wintering areas between the spectacled and white-chinned petrel sister species, by comparing data with previous information on white-chinned petrel from Phillips et al. (2006). 


\section{MATERIALS AND METHODS}

Transmitter deployment and data filtering. Spectacled petrels scavenging for discards at a pelagic longline vessel in southern Brazil were trapped using a cast net as described by Bugoni et al. (2008a). Captured birds were measured, ringed with metal bands, checked for plumage moult which indicated if birds were first year juveniles (no feather moulting) or older birds (signs of moult evident), and $1 \mathrm{ml}$ of blood was collected. Molecular sexing was carried out based on DNA extraction from blood and PCR amplification of chromodomain-helicase-DNA binding (CHD) genes with primers 2550F (Fridolfsson \& Ellegren 1999) and 2757R (R. Griffiths unpubl. data).

Satellite transmitters were attached to back feathers using waterproof Tesa ${ }^{\circledR}$ tape 4651 (Wilson et al. 1997). One $30 \mathrm{~g}$ battery-powered Platform Transmitter Terminal (PTT) from Microwave Telemetry was deployed in August 2006 and four $20 \mathrm{~g}$ battery PTTs (North Star Science and Technology) were deployed in August 2007. They correspond to 1.6 to $2.3 \%$ of petrels' body mass (1277.8 g, $\mathrm{n}=20$, Ryan 1998) and were configured to transmit continuously because we were interested in gathering as much data as possible on fine spatial and temporal scales to allow determination of day- and night-time movements and association with fishing vessels. Potential detrimental effects were minimized by limiting devices to $<3 \%$ of petrels' body mass, using waterproof tape instead of harnesses, and by tracking birds for short periods, as recommended by satellite tracking of Procellariiformes (Phillips et al. 2003). Egg laying at Inaccessible Island occurs around 20 October (Ryan 1998), thus all birds were in their wintering period when PTTs were deployed off Brazil in August.

Only standard locations (i.e. Location Classes 3 to 0) derived from at least 4 satellite uplinks (ARGOS 1996) were used. Auxiliary locations accounted for only $13.5 \%$ of all gathered locations $(n=7400)$, but because they are considered less accurate than standard ones (but see Hays et al. 2001) they were not used here. The remaining set of data was filtered to remove unrealis- tic locations assuming a maximum flight speed of $90 \mathrm{~km} \mathrm{~h}^{-1}$ (Phillips et al. 2006). Time interval between valid locations varied between PTTs, from 21 to $44 \mathrm{~min}$ on average. With a larger battery, the PTT deployed in 2006 resulted in 3167 valid locations during 49 tracked days, while the 4 PTTs deployed in 2007 resulted in a mean of $741 \pm 146$ locations (range 577 to 905) and tracked petrels during 17 to $20 \mathrm{~d}$ each (Table 1 ). In total, 6132 bird locations were used for the analysis.

Marine habitat utilization. The nonparametric fixed kernel density estimator (Wood et al. 2000) was used to determine the 80,60, 40 and $20 \%$ density contour areas. Densities contours corresponding to kernels were calculated for locations in a Lambert Equal-Area Azimuthal projection centred on the South Pole. Arcview GIS 9.x was used for calculations with Hawth's Analysis Tools for ARGIS (Beyer 2004), setting cell size at $5 \mathrm{~km}$ and parameter smoothing factor $(h)$ at $40 \mathrm{~km}$.

Study area and oceanographic features. In the SW Atlantic Ocean the coastal branch of the Falkland (or Malvinas) Current flowing northward and transporting sub-Antarctic waters $\left(4\right.$ to $15^{\circ} \mathrm{C}$ ) reaches warm waters of the Brazilian Current flowing southward and transporting tropical waters $>20^{\circ} \mathrm{C}$ (Garcia 1998). The convergence and mixture between the tropical and subAntarctic waters form the Subtropical Convergence (Garcia 1998), a highly productive area that supports important fish stocks and considerable numbers of top predators (Seeliger et al. 1998). The coastal areas over the continental shelf further benefit from mixing with the outflow of continental waters. The separation between the Brazilian and Falkland Currents varies seasonally, from 35.8 to $38.6^{\circ} \mathrm{S}$, forming a heterogeneous area between both currents up to $1000 \mathrm{~km}$ wide with many eddies and fronts (Olson et al. 1988). Farther north up to $23^{\circ} \mathrm{S}$, the penetration of relatively cold waters (14 to $17^{\circ} \mathrm{C}$ ) occurs frequently in winter, mainly on the shelf break (Campos et al. 1996), which has an important influence on the composition of the seabird community (Olmos 1997).

SST and chl a concentrations $\left(\mathrm{mg} \mathrm{m}^{-3}\right)$ were obtained from Aqua MODIS mapped products at $4 \mathrm{~km}$ cell resolution from the National Atmospheric and Space Ad-

Table 1. Procellaria conspicillata. Summary of data from the 5 tracked spectacled petrels in the southwestern Atlantic Ocean in 2006 and 2007

\begin{tabular}{|c|c|c|c|c|c|c|c|}
\hline Bird & Sex & $\begin{array}{l}\text { Tracking } \\
\text { period }\end{array}$ & $\begin{array}{c}\text { Tracked } \\
\text { days }\end{array}$ & $\begin{array}{c}\text { Number of } \\
\text { valid locations }\end{array}$ & $\begin{array}{l}\text { Total distance } \\
\text { travelled (km) }\end{array}$ & $\begin{array}{l}\text { Overall mean } \\
\text { speed }\left(\mathrm{km} \mathrm{h}^{-1}\right)\end{array}$ & $\begin{array}{l}40 \% \text { kernel } \\
\text { area }\left(\mathrm{km}^{2}\right)\end{array}$ \\
\hline 07783 & Unknown & 17 Aug-04 Oct 2006 & 49 & 3167 & 17891 & 15.3 & 75406 \\
\hline 75850 & Male & 01-20 Aug 2007 & 20 & 905 & 10124 & 22.6 & 116325 \\
\hline 75851 & Male & 01-18 Aug 2007 & 18 & 814 & 7310 & 18.4 & 39784 \\
\hline 75852 & Male & 01-17 Aug 2007 & 17 & 669 & 4501 & 12.0 & 17645 \\
\hline 75853 & Male & 06-24 Aug 2007 & 19 & 577 & 5853 & 13.4 & 16753 \\
\hline
\end{tabular}


ministration (NASA) (http://oceancolor.gsfc.nasa.gov/) through the mirror site at the University of São Paulo (http://orion.io.usp.br/los/). Bathymetry was obtained from the General Bathymetric Chart of the Ocean (GEBCO) at www.bodc.ac.uk/data/online_delivery/ gebco/.

Bathymetric domains were defined as continental shelf $(0$ to $1000 \mathrm{~m})$, shelf break (1000 to $3000 \mathrm{~m})$ and pelagic $(>3000 \mathrm{~m})$. SSTs were classified according to the definition of water masses expected to occur in the Subtropical Convergence, following Garcia (1998): tropical waters $\left(>20^{\circ} \mathrm{C}\right.$ ), sub-Antarctic waters (4 to $10^{\circ} \mathrm{C}$ ) and subtropical waters resulting from the mixture of both $\left(10\right.$ to $\left.20^{\circ} \mathrm{C}\right)$. In fact, the SST range of the sub-Antarctic waters from the Falkland Current is from 4 to $15^{\circ} \mathrm{C}$, and salinity is used with temperature to define water masses, but because we did not obtain salinity data and to avoid overlap between temperature ranges, waters were defined arbitrarily. Chlorophyll concentrations were divided into 4 classes after Hyrenbach et al. (2002): oligotrophic (concentration $\left.<0.1 \mathrm{mg} \mathrm{m}^{-3}\right)$, mesotrophic (0.1 to $\left.0.3 \mathrm{mg} \mathrm{m}^{-3}\right)$, eutrophic ( 0.3 to $1 \mathrm{mg} \mathrm{m}^{-3}$ ) and enriched waters $\left(>1 \mathrm{mg} \mathrm{m}^{-3}\right)$.

Fishing effort. Pelagic longline fishing effort for the domestic fleet was obtained through weekly visits to Itajaí and Santos harbours by Projeto Albatroz Team and in Itajaí by daily visits by the Grupo de Estudos Pesqueiros, Universidade do Vale do Itajaí (GEP-UNIVALI). Logbooks were obtained from captains and complemented with interviews, and contained information on fishing grounds $\left(1 \times 1^{\circ}\right.$ lat-long resolution) and number of hooks deployed per day or for the whole trip, restricted to the tracking period of birds.

The coverage was over $70 \%$ of the total effort for the domestic pelagic longline fleet.

Nighttime and daytime movements. Each satellite location was classified as nocturnal or diurnal using the nautical dawn and dusk definitions (i.e. the time when the center of the sun is $12^{\circ}$ below the horizon, using the calculation provided at www.srrb.noaa.gov/highlights/ sunrise/sunrise.html) which are accurate to $\pm 1 \mathrm{~min}$. Nighttime and daytime travelled distances were calculated using the great circle distance and speeds of tracked petrels calculated for each night or day period based on the first and last locations. Differences between speeds during night and day periods were tested by the Wilcoxon signed-rank test and differences between birds by the Kruskal-Wallis test.

\section{RESULTS}

\section{General movement characteristics and kernel density}

All spectacled petrels tracked in 2007 were males (based on molecular sexing), and were greater than one year old, because they were moulting body feathers (dorsum, ventral and head) when PTTs were deployed in August. The PTT deployed in 2006 worked for $1176 \mathrm{~h}$ or $156 \%$ of the expected lifetime of $750 \mathrm{~h}$. All PTTs deployed in 2007 provided uplinks for similar periods ( 17 to $20 \mathrm{~d}$ ) (Table 1 ), suggesting that all PTTs stopped transmitting due to battery exhaustion.

The single bird tagged in 2006 and 3 out of 4 birds tagged in 2007 foraged predominantly in waters of the Brazilian exlusive economic zone (EEZ) in southern Brazil. The distribution of these 4 birds formed a band oriented NE-SW, corresponding to the shelf break, from 25 to $33^{\circ} \mathrm{S}$ (Fig. 1). The bird tagged in August 2006 at $28^{\circ} \mathrm{S}$ over the continental shelf stayed over the shelf break for about $1 \mathrm{mo}$, during which it had a trip of $1 \mathrm{wk}$ to offshore waters $500 \mathrm{~km}$ east of the shelf break. From 23 September it headed towards Tristan da Cunha and Inaccessible Island in the mid-Atlantic where the species breeds. When close to the islands the bird moved northwest, crossing close to the Rio Grande Plateau where the signal was lost.

Three birds tagged in 2007 in the southern portion (33 to $34^{\circ} \mathrm{S}$ ) over relatively cold waters moved northeastward $2 \mathrm{~d}$ after tagging. The other bird (75850) also moved northeastward, but over deep waters off the Brazilian EEZ, stayed for a couple of days over the Rio

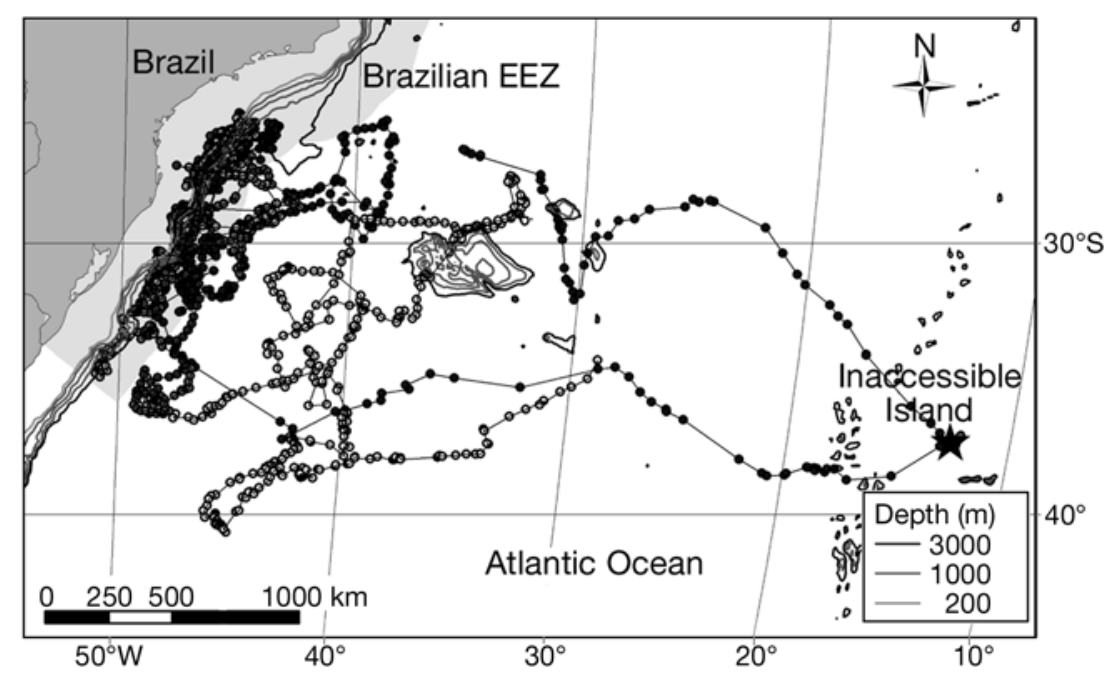

Fig. 1. Procellaria conspicillata. Distribution of satellite locations $(\mathrm{n}=6132)$ and movements of 5 spectacled petrels tracked in winter 2006 (closed circles) and 2007 (open circles) in relation to bathymetry. EEZ: exclusive economic zone 
Grande Plateau, after heading southwest up to $41^{\circ} \mathrm{S}$ and northwest again.

Core home range areas defined by kernel densities 20 and $40 \%$ demonstrated intense use of the shelf break between 25 and $31^{\circ} \mathrm{S}$ (Fig. 2), with $40 \%$ kernel areas between 16753 to $116325 \mathrm{~km}^{2}$ (Table 1). The largest home range area belonged to the bird that did not stay over the shelf break as all the others, but wandered considerably over offshore waters. The kernel area generated by all 2006 and 2007 locations was $34007 \mathrm{~km}^{2}$ at $20 \%$ density and $596545 \mathrm{~km}^{2}$ at $80 \%$, and included some small offshore patches (Fig. 2).
Table 2. Procellaria conspicillata. Activity levels of spectacled petrels in the southwestern Atlantic Ocean in 2006 and 2007 during day- and nighttime periods as measured by distance travelled and speed. ${ }^{*}$ Significant at $p<0.05$; ns: differences not significant

\begin{tabular}{|c|c|c|c|c|}
\hline Bird & $\begin{array}{c}\text { Distance } \\
\text { travelled day }(\mathrm{km})\end{array}$ & $\begin{array}{c}\text { Distance travelled } \\
\text { night }(\mathrm{km})\end{array}$ & $\begin{array}{l}\text { Mean speed } \\
\text { day }\left(\mathrm{km} \mathrm{h}^{-1}\right)\end{array}$ & $\begin{array}{l}\text { Mean speed } \\
\text { night }\left(\mathrm{km} \mathrm{h}^{-1}\right)\end{array}$ \\
\hline $07783^{a}$ & $184.8 \pm 174.3$ & $104.0 \pm 95.8^{*}$ & $18.0 \pm 13.8$ & $13.8 \pm 10.8^{\mathrm{ns}}$ \\
\hline 75850 & $227.3 \pm 84.6$ & $232.1 \pm 100.9^{\text {ns }}$ & $21.2 \pm 7.9$ & $23.5 \pm 9.7^{\mathrm{ns}}$ \\
\hline 75851 & $215.8 \pm 113.0$ & $166.4 \pm 83.8^{\mathrm{ns}}$ & $19.2 \pm 9.0$ & $17.2 \pm 7.5^{\mathrm{ns}}$ \\
\hline 75852 & $97.9 \pm 56.2$ & $132.0 \pm 88.1^{\mathrm{ns}}$ & $9.0 \pm 4.5$ & $14.4 \pm 7.5^{\mathrm{ns}}$ \\
\hline 75853 & $125.9 \pm 122.6$ & $129.0 \pm 83.7^{\mathrm{ns}}$ & $12.7 \pm 12.3$ & $14.7 \pm 7.7^{\mathrm{ns}}$ \\
\hline \multicolumn{5}{|c|}{$\begin{array}{l}\text { a During last } 10 \mathrm{~d} \text { it headed towards Inaccessible Island where the species } \\
\text { breeds, travelling a mean of } 426.1 \pm 250 \mathrm{~km} \text { during the day (speed } 38.4 \pm \\
16.3 \mathrm{~km} \mathrm{~h}^{-1} \text { ) and } 168.2 \pm 131.7 \mathrm{~km} \text { at night (speed } 22.6 \pm 14.4 \mathrm{~km} \mathrm{~h}^{-1} \text { ) }\end{array}$} \\
\hline
\end{tabular}

\section{Diel travelled distances and speed}

Mean speed varied between birds (Kruskal-Wallis, $H=31.9, \mathrm{df}=4, \mathrm{p}<0.001)$, but there was no difference between day and night (Wilcoxon signed- rank test, $\mathrm{p}=0.9$ ). Every bird moved from 98 to $227 \mathrm{~km}$ on average during daylight hours, with average speed varying from 9 to $21 \mathrm{~km} \mathrm{~h}^{-1}$ (Table 2). At night the average distance varied from 104 to $232 \mathrm{~km}$, and speed varied from 14 to $24 \mathrm{~km} \mathrm{~h}^{-1}$. Results were similar when analysing each bird individually, with no difference between speeds during day and night, with the exception of the bird tracked in 2006 which travelled further during daylight (Table 2). Thus, in spite of individual differences, the spectacled petrel has similar activity levels during night and day. Furthermore, distances

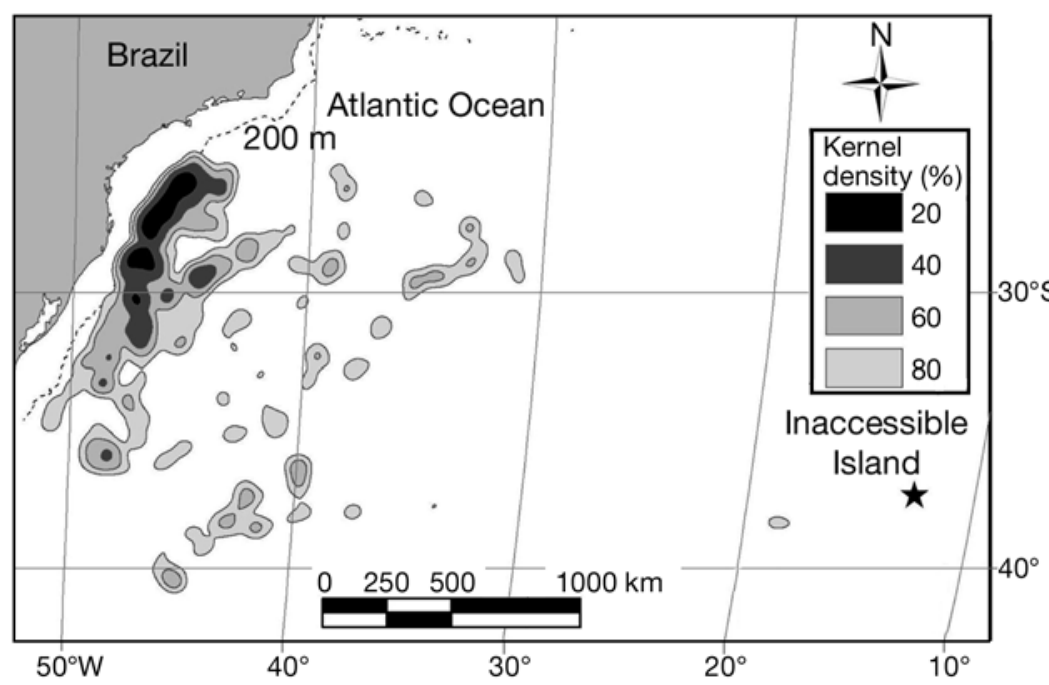

Fig. 2. Procellaria conspicillata. Kernel density distribution of 5 spectacled petrels tracked during wintering period in 2006 and 2007 and speed during daytime were correlated with distances and speed during the subsequent night in 4 out of 5 birds (correlation coefficients from $r=0.27$ to $r=$ $0.66, \mathrm{n}=15$ to 44 , all $\mathrm{p}<0.05$ ). Thus, the tracked birds spent several days travelling between foraging grounds, during which periods they sustained high speed and travelled farther. These spectacled petrels also exhibited periods of low mobility, travelling short distances more slowly. The latter case is expected to represent periods of foraging activity intercalated with periods of rest on the water.

\section{Oceanographic domains}

The 4 bathymetric domains were not used evenly by the birds, which clearly preferred the shelf break and offshore deep waters (Figs. 1 \& 2) rather than the continental shelf (Fig. 3). Fifty-two percent of locations were over water $>3000 \mathrm{~m}, 34 \%$ between 1000 and $3000 \mathrm{~m}$ and $14.3 \%$ over the continental shelf $(<1000 \mathrm{~m})$. Average water depth at kernel $20 \%$ was $1043 \pm 794 \mathrm{~m}$ and at $40 \%$ was $2250 \pm 1353 \mathrm{~m}$ (Table 3).

Birds stayed over warm subtropical and tropical waters (mean $\mathrm{SST}=$ $22.05 \pm 0.31^{\circ} \mathrm{C}$ and $20.95 \pm 1.25^{\circ} \mathrm{C}$ in 2006 and 2007, respectively). Only $1 \%$ of locations were over cold waters of the Falkland Current (Fig. 3), which were present in the area over the continental shelf and southward (Fig. 4). Birds sampled in 2007 were tagged over cold waters, but moved northward or offshore soon after PTT deployment. There was a clear prefer- 
ence for subtropical and, to a lesser extent, tropical waters (Fig. 3).

Mesotrophic waters (chl a density between 0.1 and $0.3 \mathrm{mg} \mathrm{m}^{-3}$ ) represented $81 \%$ of all locations, with
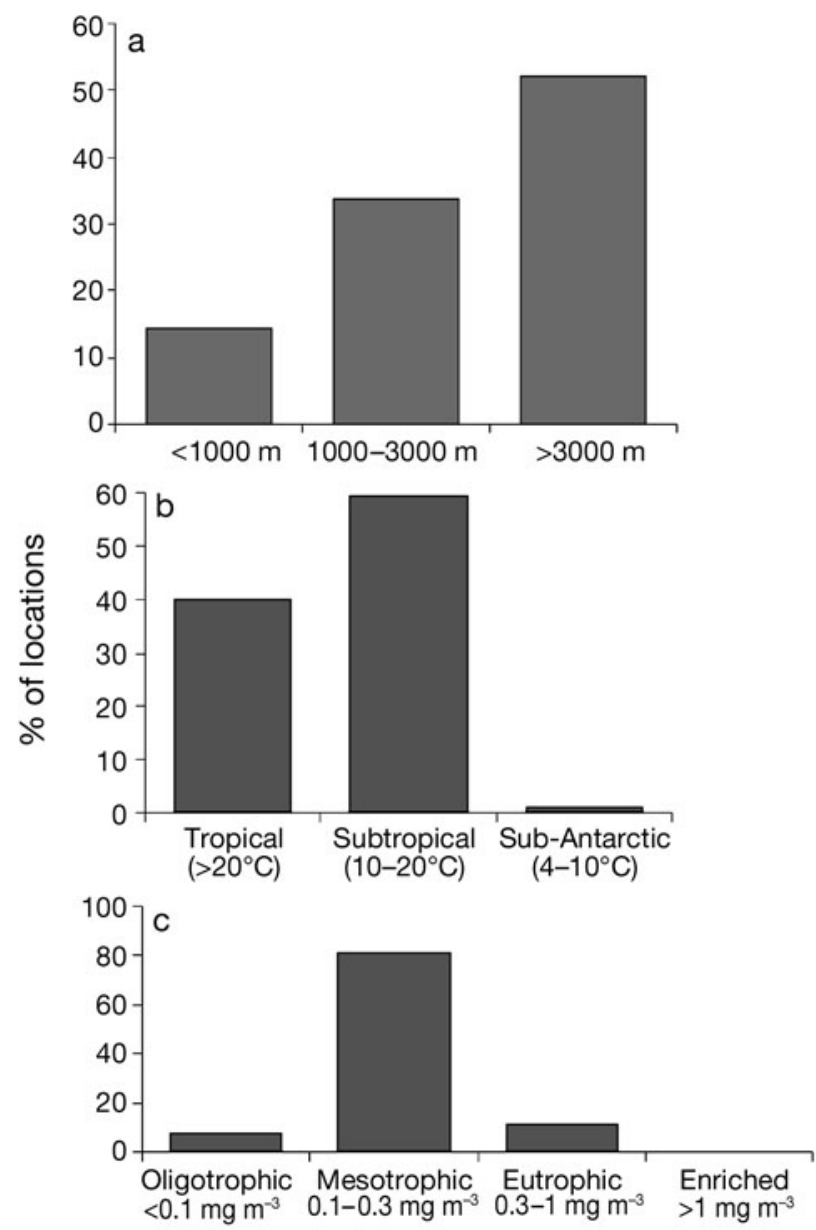

Fig. 3. Procellaria conspicillata. Frequency of locations (\%) of spectacled petrels within each (a) bathymetric domain, (b) sea surface temperature range and (c) chl a concentration class $\left(\mathrm{mg} \mathrm{m}^{-3}\right)$ minor proportion of oligotrophic and eutrophic waters ( 8 and $12 \%$, respectively) (Figs. 3 \& 5). Eutrophic and even enriched waters were present at the area during the tracking period near the coast and southward, but were not used frequently by birds. The $20 \%$ kernel density areas used by birds occurred over waters with chl a densities between 0.14 and $0.95 \mathrm{mg} \mathrm{m}^{-3}$, averaging $0.301 \pm 0.71 \mathrm{mg} \mathrm{m}^{-3}$ in 2006 and $0.281 \pm 0.65 \mathrm{mg}$ $\mathrm{m}^{-3}$ in 2007 (Table 3).

\section{Overlap with longline fishery}

The pelagic longline fishery effort in August 2007 was concentrated along the shelf break off southern Brazil, in a SW-NE oriented band, similar to the distribution of satellite locations and the kernel distributions of birds (Fig. 6). The fishing effort of the domestic longline fleet was concentrated between 26 and $32^{\circ} \mathrm{S}$, where $77.5 \%$ of hooks were deployed during the tracking period ( $\mathrm{n}=787834$ hooks sampled). The areas with the highest density utilization by birds (kernel density < 40\%) were those with highest fishing effort. Considering all 2007 locations, $47 \%$ were inside quadrants where pelagic longline hooks were deployed, even considering one bird that spent all time far offshore in an area where fishing data was not available. Furthermore, the number of locations was higher in quadrants with the highest number of hooks deployed (Spearman rank correlation, $\mathrm{r}_{\mathrm{S}}=0.47, \mathrm{n}=23, \mathrm{p}=0.027$ ), demonstrating that birds stayed longer in areas of intense pelagic longline fishery. It is also noticeable that although birds were tagged in the southern areas where the fishing effort was low, they subsequently moved and stayed in areas with intense fishing activities to the north. One bird had no association with this fleet by moving over a vast area over international waters where the fleet was not operating during this time.

Table 3. Procellaria conspicillata. Mean \pm SD (range) of water depth, sea surface temperature (SST) and chl a concentration within different kernel density distributions of spectacled petrels in the southwestern Atlantic Ocean

\begin{tabular}{|c|c|c|c|c|c|c|}
\hline $\begin{array}{l}\text { Kernel density } \\
(\%)\end{array}$ & $\begin{array}{c}\text { Kernel area }\left(\mathrm{km}^{2}\right) \\
2006 \text { and } 2007\end{array}$ & $\begin{array}{c}\text { Depth }(\mathrm{m}) \\
2006 \text { and } 2007\end{array}$ & $\begin{array}{l}\mathrm{SST}\left({ }^{\circ} \mathrm{C}\right) \\
2006\end{array}$ & $\begin{array}{l}\mathrm{SST}\left({ }^{\circ} \mathrm{C}\right) \\
2007\end{array}$ & $\begin{array}{c}\mathrm{Chl} \mathrm{a}\left(\mathrm{mg} \mathrm{m}^{-3}\right) \\
2006\end{array}$ & $\begin{array}{c}\mathrm{Chl} \mathrm{a}\left(\mathrm{mg} \mathrm{m}^{-3}\right) \\
2007\end{array}$ \\
\hline 20 & 34008 & $\begin{array}{l}1043 \pm 794 \\
(153-2138)\end{array}$ & $\begin{array}{c}22.05 \pm 0.31 \\
(21.40-22.60)\end{array}$ & $\begin{array}{c}20.95 \pm 1.25 \\
(15.40-21.70)\end{array}$ & $\begin{array}{c}0.301 \pm 0.71 \\
(0.14-0.83)\end{array}$ & $\begin{array}{c}0.281 \pm 0.65 \\
(0.15-0.95)\end{array}$ \\
\hline 40 & 105194 & $\begin{array}{c}2250 \pm 1353 \\
(121-4758)\end{array}$ & $\begin{array}{c}20.79 \pm 1.20 \\
(17.60-22.60)\end{array}$ & $\begin{array}{l}19.36 \pm 2.71 \\
(4.20-21.90)\end{array}$ & $\begin{array}{c}0.273 \pm 0.63 \\
(0.12-2.50)\end{array}$ & $\begin{array}{c}0.253 \pm 0.53 \\
(0.12-2.29)\end{array}$ \\
\hline 60 & 254733 & $\begin{array}{c}3229 \pm 1493 \\
(105-5165)\end{array}$ & $\begin{array}{l}18.84 \pm 2.91 \\
(6.90-22.60)\end{array}$ & $\begin{array}{l}18.10 \pm 3.03 \\
(3.20-22.00)\end{array}$ & $\begin{array}{c}0.253 \pm 0.57 \\
(0.08-2.56)\end{array}$ & $\begin{array}{c}0.203 \pm 0.53 \\
(0.07-2.55)\end{array}$ \\
\hline 80 & 596545 & $\begin{array}{c}3701 \pm 1324 \\
(93-5186)\end{array}$ & $\begin{array}{l}17.76 \pm 2.87 \\
(6.80-22.60)\end{array}$ & $\begin{array}{l}17.21 \pm 3.16 \\
(2.59-22.10)\end{array}$ & $\begin{array}{c}0.243 \pm 0.55 \\
(0.07-3.70)\end{array}$ & $\begin{array}{c}0.176 \pm 0.54 \\
(0.07-3.70)\end{array}$ \\
\hline
\end{tabular}




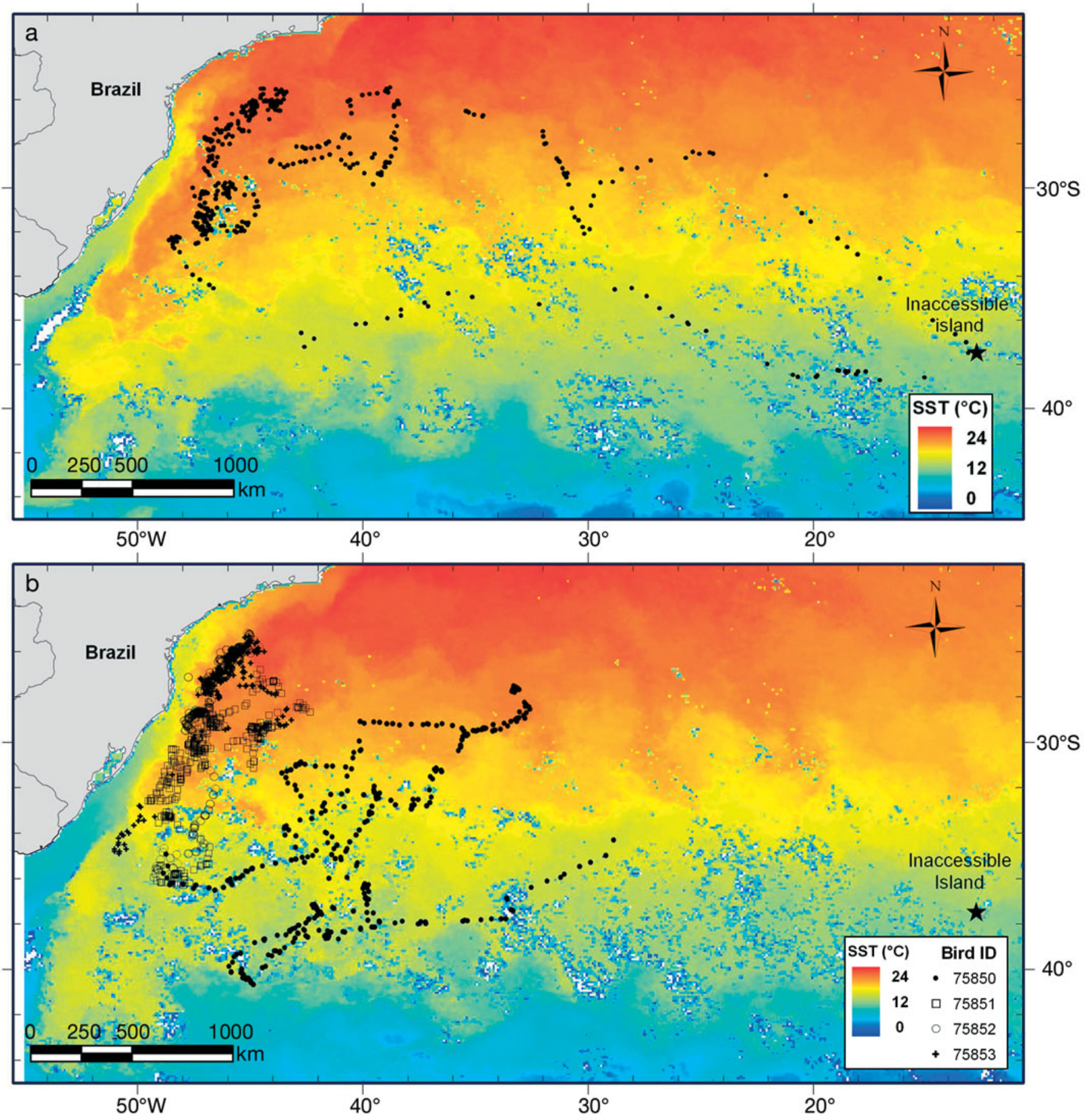

Fig. 4. Procellaria conspicillata. Habitat preference of spectacled petrels tracked during wintering period in (a) 2006 and (b) 2007 in relation to water masses defined according to sea surface temperature (SST)

\section{DISCUSSION}

\section{Foraging areas of wintering birds}

The distribution of spectacled petrels at sea is poorly known, and this is the first study to describe the forag- ing areas of the species based on satellite telemetry. Most studies using satellite technologies to track seabirds deploy PTTs in colonies and are restricted to periods of breeding, just after chick fledging or when adults fail to breed (but see Hyrenbach \& Dotson 2003, Suryan et al. 2007). During wintering periods seabirds 

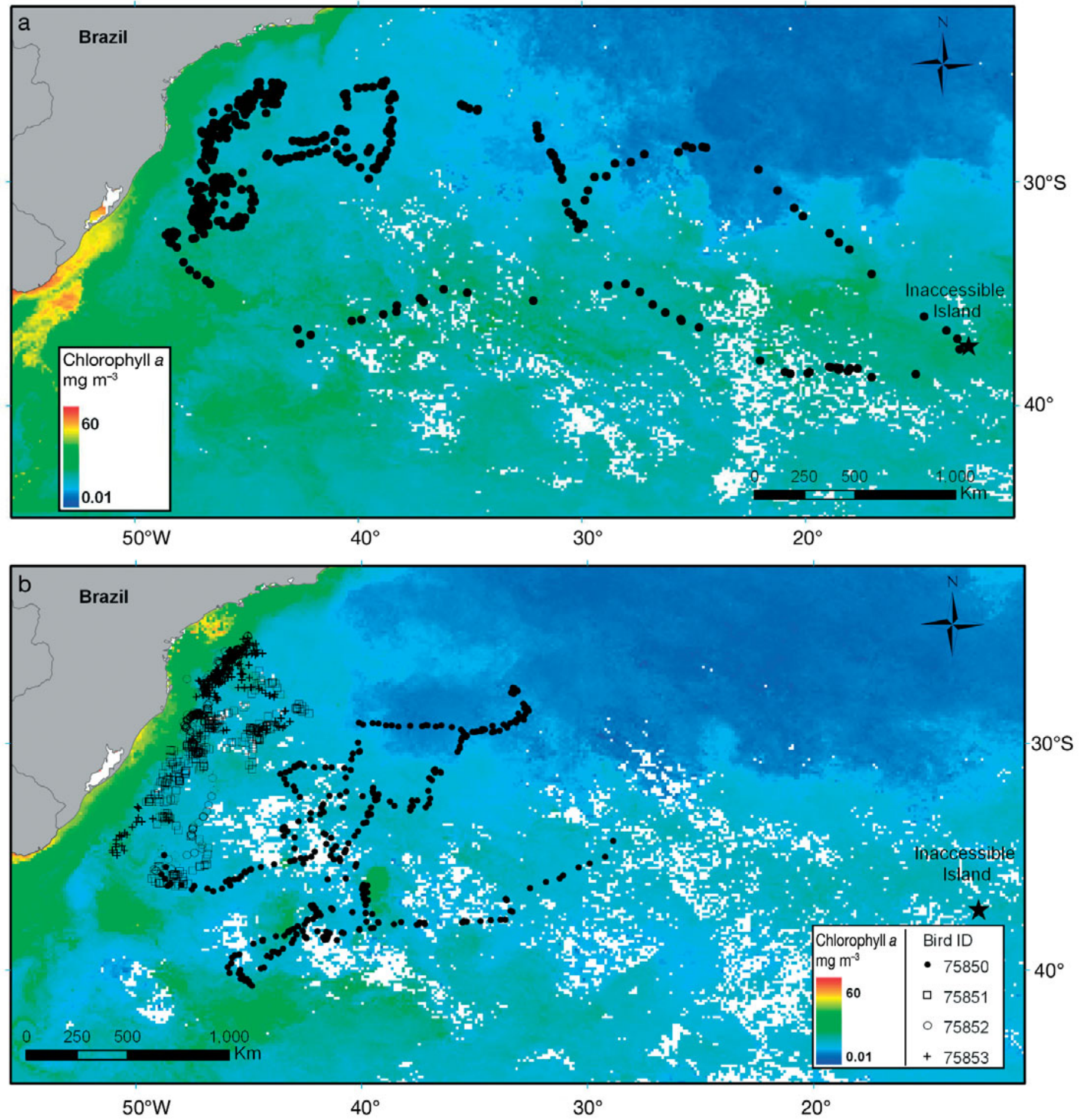

Fig. 5. Procellaria conspicillata. Habitat preference of spectacled petrels tracked during wintering period in (a) 2006 and (b) 2007 in relation to chl a concentration

are no longer central place-foragers, and are able to explore the marine environment more widely, changing foraging grounds if convenient or remaining within particular oceanographic areas or fisheries (Bugoni et al. 2005, Phillips et al. 2007). The long displacement of
3 birds just after tagging, from $34^{\circ} \mathrm{S}$ to $29-30^{\circ} \mathrm{S}$, is explained by birds taking advantage of polar fronts crossing the area, which typically have strong S-SW winds and are common during winter and spring. During satellite deployment, calm wind conditions 


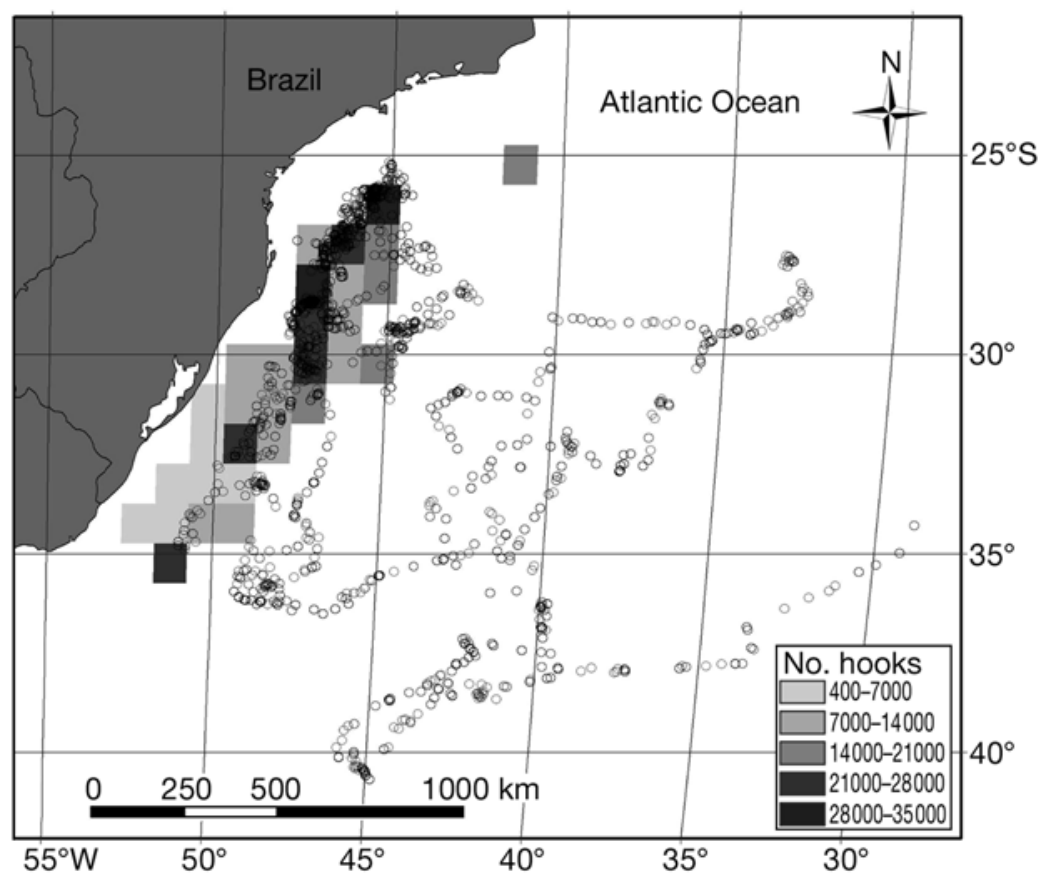

Fig. 6. Distribution of fishing effort in number of hooks deployed by the Brazilian domestic longline fleet during the 2007 tracking period of spectacled petrel

predominated and there were just a few spectacled petrels over cold waters. Albatrosses and petrels commonly take advantage of tail and cross winds (Jouventin \& Weimerskirch 1990, Falk \& Møller 1995) since the costs of displacement are reduced with high-speed winds (Furness \& Bryant 1996).

The bird tracked in 2006 headed towards Tristan da Cunha at the end of the tracking period after a long period in the SW Atlantic (Fig. 1), and thus was probably an adult bird or a prospecting immature. Birds tracked in 2007 were in late moult stage, probably preparing for breeding, as spectacled petrels are expected to replace wing and tail feathers before body feathers (Warham 1990).

All birds except one used the shelf break area extensively, as demonstrated by the kernel analysis (Fig. 2), with occasional incursions to offshore deep waters or movements to breeding grounds. However, these movements were rapid, with no particular area in international waters used preferentially. It has been demonstrated that the Rio Grande Plateau, a shallow area around $30^{\circ} \mathrm{S}$ to $35^{\circ} \mathrm{W}$ (Fig. 1), contains large flocks of spectacled petrels throughout the year and when they meet the Brazilian longline fleet during summer (Projeto Albatroz unpubl. data), and this area was clearly of interest to tracked birds. Despite being trapped behind longline vessels for PTT deployment, tracked birds are thought to be representative of the population because other banded birds of the same species remained for short periods attending the vessel (Bugoni 2008). Birds flew 100s of km immediately after PTT deployment to join areas of intense longline fishing with typical oceanographic characteristics for the species. The distribution of tracked birds from the present study is further corroborated by censuses of birds in the area (Olmos 1997, Neves et al. 2006a).

\section{Diel foraging activities}

Spectacled petrels travelled similar distances at similar speeds during day and night. These results contrast with previous studies of other albatrosses and petrels, for which day and night differences in these parameters were found. Some studies show albatrosses and petrels flying further and faster at night (Klomp \& Schultz 2000, Nel et al. 2000, Hyrenbach et al. 2002) or landing more frequently during the day (Fernández \& Anderson 2000, Phalan et al. 2007). Catry et al. (2004) found that grey-headed albatross Thalassarche chrysostoma spent $94 \%$ of the night on the water, apparently sleeping as they consumed only $26 \%$ of their prey during night. Nel et al. (2000) assumed that the speed of $<10 \mathrm{~km} \mathrm{~h}^{-1}$ recorded for grey-headed albatross during daylight hours was indicative of concentrated foraging. In the present study, correlations between day and night speeds and distances travelled in subsequent periods suggest that spectacled petrel activity might be divided into 2 different types, representing different foraging strategies: (1) periods of one or more days performing long and fast flights, apparently commuting between foraging areas or between breeding and foraging grounds; and (2) periods when they stay relatively stationary over productive foraging grounds or when attending vessels. However, this pattern seems to be independent of day or night. Weimerskirch \& Guionnet (2002) determined that 4 albatross species spent 55 to $65 \%$ of their time in flight, and at night they spent most of their time sitting on the water. Catry et al. (2004), using stomach temperature loggers, satellite tracking and wet-dry activity loggers, demonstrated that when sitting on the water under complete darkness, greyheaded albatrosses were able to ingest a considerable amount of food. Pinaud \& Weimerskirch (2007) also found long stationary periods at night when analysing 7 satellite tracked Procellariiformes, including the white-chinned petrel. From these results of diel activ- 
ity in a range of seabirds, it is not clear if lower activity levels at night, measured as speed or absolute travelled distance, represent foraging behaviour, birds resting on the water, or even opportunistic feeding during resting periods at night. Procellariiformes, and spectacled petrels in particular, are frequently observed roosting at sea in flocks after feeding to satiation or in early morning before the longline hauling starts (L. Bugoni pers. obs.). In addition, slow speed and short distances covered by birds following fishing vessels is also expected during longline hauling, when vessel speed is 5 to $10 \mathrm{~km} \mathrm{~h}^{-1}$. When birds arrive in foraging grounds or find a profitable feeding area, they appear to move short distances and show lower mean speeds, adjusting the scale of movement and speed according to the species and environmental characteristics (Weimerskirch et al. 1997, Pinaud \& Weimerskirch 2005, 2007). A complementary approach is necessary for a better understanding of diel foraging activities; this can be achieved by the simultaneous use of satellite transmitters and stomach temperature loggers (e.g. Catry et al. 2004).

Furthermore, some individuals appear to behave differently, by covering larger distances away from longline fishing grounds, such as bird 75850 (Figs. 4 $\& 5)$. The density distribution for this bird was not concentrated in a particular area (Fig. 2), which suggests that if this individual attended some fishing vessels it did so only for short periods. The other birds could be flying between vessels operating nearby, but to investigate the association of each bird with a particular vessel we would require higher resolution data, with birds and vessels tracked by GPS satellite transmitters. Whether Bird 75850 was commuting from one vessel to another or feeding on naturally available prey is unknown, but individual feeding preferences, with some individuals more prone to scavenge for fishing discards or attend different foraging grounds, is a well described phenomenon in seabirds (Freeman et al. 2001, Phillips et al. 2005b) and could have occurred in this case.

\section{Oceanography and segregation with white-chinned petrel}

Spectacled petrels prefer warm, offshore and mesotrophic or oligotrophic waters of the SW Atlantic Ocean. The cold waters of the Falkland Current are more evident over the continental shelf and north up to around $30^{\circ} \mathrm{S}$ adjacent to southern Brazil, where productivity is high (Figs. 4 \& 5). Coastal cold and productive waters are used extensively by wintering whitechinned petrels (Phillips et al. 2006), but were clearly avoided by spectacled petrels, as they were tagged in the south but moved quickly to the north, and high density use of the region by both species did not overlap extensively. The density distribution in 2006 and 2007 also demonstrated a clear preference for warm and mesotrophic waters found offshore and further north. The segregation pattern demonstrated here is in accordance with low numbers of spectacled petrels among stranded birds on the coastline, while the white-chinned petrel is more common (Colabuono \& Vooren 2006). Additionally, the high abundance of spectacled petrels in southeastern Brazil (Olmos 1997) and their association with deep waters has been demonstrated by at-sea censuses and canonical analysis (Neves et al. 2006a). That these closely related species show remarkably different at-sea distributions and association with SST, bathymetry and productivity gives additional support for the distinctiveness of taxa and the specific status proposed by Ryan (1998) for the spectacled petrel based on morphometric data, plumage characteristics, vocalizations and playback responses. Furthermore, while both are associated with the pelagic longline fishery occurring over the shelf break, white-chinned petrels are expected to interact more extensively with a range of other fisheries taking place over the continental shelf, such as bottom trawling, gillnet and bottom longline. Environmental heterogeneity such as that found in the Subtropical Convergence area in the SW Atlantic Ocean, coupled with habitat selection, spatial segregation and differences in behavior, provide a basis for species coexistence in albatrosses and petrels (Waugh \& Weimerskirch 2003, Phillips et al. 2005a, 2007).

\section{Interactions with fisheries}

The Brazilian pelagic longline fishing effort targeting swordfish Xiphias gladius, tunas Thunnus spp. and sharks (mainly blue shark Prionace glauca) has varied over recent years, with an increase in the proportion of the domestic fleet to detriment of the leased fleet, and an overall effort of 9 million hooks in 2006 (Bugoni et al. 2008c). This fishery and the similar Uruguayan pelagic fleet (Jiménez \& Domingo 2007) incidentally capture spectacled petrels mainly during winter months, when the fleet concentrates efforts between 20 and $50^{\circ} \mathrm{S}$. In addition, spectacled petrels are captured in a range of hook-and-line fisheries during summer months (Bugoni et al. 2008b): the highest capture rate per species occurs in the handlining fishery targeting tuna, but high rates also occur in the slow trolling fishery targeting bigeye tuna Thunnus obesus. The surface longline fishery for dolphinfish Coryphaena hippurus also has a high potential for interaction with 
spectacled petrels during summer (Bugoni et al. 2008b). Moreover, birds are expected to spend considerable time in Uruguayan and Argentinean waters during the summer, when their preferred warm waters spread south. They will also spend time in international waters, where longline fleets from these and other countries such as Japan, Taiwan, Korea and Spain deploy considerable numbers of hooks (Tuck et al. 2003).

The global spectacled petrel population was estimated to be at least 20000 ind., continuing an apparent recovery from a very small population in early 20th century (Ryan et al. 2006). The longline fishery is the common cause for concern for the conservation of several species of albatross and petrel from Tristan da Cunha and Gough Islands (Cuthbert et al. 2003, 2005, Neves et al. 2006a). A crucial step in the conservation of albatross and petrel populations affected by fisheries is describing the population range, assessing the susceptibility of birds and highlighting national responsibilities (Hyrenbach \& Dotson 2003). In this way, the present study determined the distribution of spectacled petrels and demonstrated a substantial overlap with the Brazilian pelagic longline fleet during winter.

Similar to our results, Terauds et al. (2006) found high overlap between the distributions of satellite tracked black-browed albatrosses and trawler fishing around Macquarie Island. On the other hand, little overlap between longline fishing and satellite tracked black-footed Phoebastria nigripes and Laysan P. immutabilis albatrosses was found in the North Pacific Ocean (Hyrenbach et al. 2002), a discrepancy attributed to different sampling periods. In the S-SW Atlantic Ocean, some attempts have been made to quantify the overlap between longline fisheries and tracked albatrosses and petrels (e.g. Cuthbert et al. 2005, Phillips et al. 2006). However, data on fishing effort used for comparison is frequently temporally non-overlapping with bird tracking periods, and is often based on incomplete datasets (Tuck et al. 2003), or fishing effort is only available on large scales; for example, data provided by the International Commission for the Conservation of Atlantic Tuna (ICCAT) is in quadrants of $5 \times 5^{\circ}$. In addition to the problems of using incomplete, large-scale data or temporal incongruence among fishing and bird data, the inherent dynamic nature of pelagic fisheries causes severe limitations in data analysis and interpretation (Hyrenbach \& Dotson 2003, Bugoni et al. 2008c). In investigations of seabird distributions and overlap with fisheries, both temporal scale and a fine-scale spatial resolution are essential (Hyrenbach \& Dotson 2003).

Phillips et al. (2006) found higher travelled distances and speeds of white-chinned petrels at night, suggest- ing low foraging activities, which contrasts with results from the present study indicating similar speeds and distances travelled by day and night for the spectacled petrel. The role of this behavioural difference between white-chinned and spectacled petrels is unclear, as is how it relates to risk of incidental capture on longlines. A possible explanation for the higher mortality of white-chinned petrel in comparison with spectacled petrel in the pelagic longline fishery (Bugoni et al. 2008c) could be differential age distribution in the study area, as the former are mostly juveniles and the latter are mostly subadults and adults (Bugoni 2008).

\section{Conservation implications}

Recently, the bycatch of seabirds has been addressed by the Brazilian government and nongovernmental organizations with the launch of the National Plan of Action for the Conservation of Albatrosses and Petrels in 2006 (Neves et al. 2006b); the ratification of the Agreement for the Conservation of Albatrosses and Petrels (ACAP) in July 2008; the testing of mitigation measures such as bird scaring lines and blue-dyed baits (Neves et al. 2008); the satellite tracking of each longline vessel of the leased fleet, the tracking of the domestic fleet, implemented in 2006; and the proposed coverage of the fleet by onboard observers, currently under consideration by the Brazilian Environmental Agency. These actions constitute significant progress towards the mitigation of the global problem of incidental capture of albatrosses and petrels in fisheries. However, no mitigation measure is expected to be effective without strong enforcement (Bugoni et al. 2008b). The importance of Brazilian waters and the implications of the national longline fleet for the conservation of spectacled petrel have been demonstrated in the present study, which certainly extends to other jurisdictional countries and international fleets at different periods of the annual cycle of the species. Overall, spectacled petrels have been demonstrated to prefer relatively warm and oligotrophic waters over the shelf break and offshore, with great overlap with the pelagic longline fishery. The spectacled petrel remains a vulnerable, poorly known species that is strongly associated with fishing vessels, with a population concentrated in the SW Atlantic Ocean. Therefore, Brazil and other countries fishing in the area under the ICCAT Regional Fishery Organization jurisdiction have a critical role in the conservation of this species.

Acknowledgements. Authors acknowledge the Projeto Albatroz team, which contributed to this project in several ways particularly for gathering fishing effort data at harbours and 
Captain C. Oliveira and crew of the FV 'Akira V' for logistic support onboard. Thanks are also due to K. Griffiths for genetic sexing of birds, H. Beyer for software advice, G. C. Feldman (NASA, USA) and P. S. Polito (USP, Brazil), who gave us all support for chl a data access and usage. H. Beyer (University of Glasgow) helped us with GIS software and kernel analysis. P. R. Pezzuto from GEP-UNIVALI provided us valuable unpublished data on longline fishing effort. This study was carried out with permits from the Brazilian Environmental Agency (IBAMA) Nos. 0128931BR, 203/2006, 02001.005981/ 2005, 023/2006, 040/2006 and 1282/1, and International Animal Health Certificate No. 0975-06, issued by the Brazilian Government. The Scottish Executive Rural Directorate also kindly provided us the permit POAO 2007/91 to import samples into Scotland. L.B. received a CAPES Scholarship. Transmitters deployed in 2007 were granted by North Star Science and Technology and American Bird Conservancy. Early drafts were greatly benefited from suggestions from R. A. Phillips and anonymous referees.

\section{LITERATURE CITED}

ARGOS (1996) User's manual. CLS/Service Argos, Toulouse Awkerman JA, Fukuda A, Higuchi H, Anderson DJ (2005) Foraging activity and submesoscale habitat use of waved albatrosses Phoebastria irrorata during chick-brooding period. Mar Ecol Prog Ser 291:289-300

Barnes KN, Ryan PG, Boix-Hinzen C (1997) The impact of the hake Merluccius spp. longline fishery off South Africa on procellariiform seabirds. Biol Conserv 82:227-234

Beyer HL (2004) Hawth's analysis tools for ArcGIS. Available at: www.spatialecology.com/htools

BirdLife International (2004) Tracking ocean wanderers: the global distribution of albatrosses and petrels. Results from the Global Procellariiform Tracking Workshop, 15 September 2003, Gordon's Bay, South Africa. BirdLife International, Cambridge. Available at: www. birdlife.org/action/science/species/seabirds/tracking_ocean _wanderers.pdf

BirdLife International (2008) Species factsheet: Procellaria conspicillata. BirdLife International, Cambridge. Available at: www.birdlife.org

Bugoni L (2008) Ecology and conservation of albatrosses and petrels at sea off Brazil. PhD Thesis, University of Glasgow

Bugoni L, Cormons TD, Boyne AW, Hays H (2005) Feeding grounds, daily foraging activities, and movements of common terns in southern Brazil, determined by radiotelemetry. Waterbirds 28:468-477

Bugoni L, Neves TS, Peppes FV, Furness RW (2008a) An effective method for trapping scavenging seabirds at sea. J Field Ornithol 79:308-313

Bugoni L, Neves TS, Leite-Jr NO, Carvalho D and others (2008b) Potential bycatch of seabirds and turtles in hookand-line fisheries of the Itaipava Fleet, Brazil. Fish Res 90:217-224

Bugoni L, Mancini PL, Monteiro DS, Nascimento L, Neves TS (2008c) Seabird bycatch in the Brazilian pelagic longline fishery and a review of capture rates in the southwestern Atlantic Ocean. Endang Species Res 5:137-147

Camphuysen KCJ, van der Meer J (2000) Notes on the distribution of the spectacled petrel Procellaria conspicillata in the Southern Ocean. Atl Seabirds 2:13-18

Campos EJD, Lorenzzetti JA, Stevenson MR, Stech JL, Souza RB (1996) Penetration of waters from the BrazilianMalvinas confluence region along the South American Continental Shelf up to $23^{\circ} \mathrm{S}$. Ann Acad Bras Cienc 68:49-58
Catry P, Phillips RA, Phalan B, Silk JRD, Croxall JP (2004) Foraging strategies of grey-headed albatrosses Thalassarche chrysostoma: integration of movements, activity and feeding events. Mar Ecol Prog Ser 280:261-273

Cherel Y, Weimerskirch H, Duhamel G (1996) Interactions between longline vessels and seabirds in Kerguelen waters and a method to reduce seabird mortality. Biol Conserv 75:63-70

Colabuono FA, Vooren CM (2006) Hábitos alimentares de alguns albatrozes e petréis na região sul do Brasil. In: Neves T, Bugoni L, Rossi-Wongtschowski CLB (eds) Aves oceânicas da região sudeste-sul do Brasil. REVIZEE, São Paulo, p 83-102

> Cuthbert R, Ryan PG, Cooper J, Hilton G (2003) Demography and population trends of the Atlantic yellow-nosed albatross. Condor 105:439-452

Cuthbert R, Hilton G, Ryan P, Tuck GN (2005) At-sea distribution of breeding Tristan albatrosses Diomedea dabbenena and potential interactions with pelagic longline fishing in the South Atlantic Ocean. Biol Conserv 121: 345-355

Enticott JW, O'Connell M (1985) The distribution of the spectacled form of the white-chinned petrel (Procellaria aequinoctialis conspicillata) in the south Atlantic Ocean. Br Antarct Surv Bull 66:83-86

Falk K, Møller S (1995) Satellite tracking of high-arctic northern fulmars. Polar Biol 15:495-502

Fernández P, Anderson DJ (2000) Nocturnal and diurnal foraging activity of Hawaiian albatrosses detected with a new immersion monitor. Condor 102:577-584

> Freeman AND, Wilson KJ, Nicholls DG (2001) Westland petrels and the hoki fishery: determining co-occurrence using satellite telemetry. Emu 101:47-56

Fridolfsson AK, Ellegren H (1999) A simple and universal method for molecular sexing of non-ratite birds. J Avian Biol 30:116-121

Furness RW (2003) Impacts of fisheries on seabird communities. Sci Mar 67:33-45

> Furness RW, Bryant DM (1996) Effect of wind on field metabolic rates of breeding northern fulmars. Ecology 77 : 1181-1188

Gales R (1998) Albatross populations: status and threats. In: Robertson G, Gales R (eds) Albatross: biology and conservation. Surrey Beatty \& Sons, Chipping Norton, p 20-45

Garcia CAE (1998) Oceanografia física. In: Seeliger U, Odebrecht C, Castello JP (eds) Os ecossistemas costeiro e marinho do extremo sul do Brasil. Ecoscientia, Rio Grande, p 104-106

Hays GC, Åkesson S, Godley BJ, Luschi P, Santidrian P (2001) The implications of location accuracy for the interpretation of satellite-tracking data. Anim Behav 61:1035-1040

Hyrenbach KD, Dotson RC (2003) Assessing the susceptibility of female black-footed albatross (Phoebastria nigripes) to longline fisheries during their post-breeding dispersal: an integrated approach. Biol Conserv 112:391-404

> Hyrenbach KD, Fernández P, Anderson DJ (2002) Oceanographic habitats of two sympatric North Pacific albatrosses during the breeding season. Mar Ecol Prog Ser 233: 283-301

Imberti S (2002) At-sea records of three rarely reported petrel species in the south-western Atlantic Ocean. Mar Ornithol 30:32-33

Jiménez S, Domingo A (2007) Albatros y petreles: su interacción con la flota de palangre pelágico uruguaya en el Atlántico Sudoccidental. Collect Vol Sci Pap ICCAT 60: $2110-2117$ 
Jouventin P, Weimerskirch H (1990) Satellite tracking of wandering albatrosses. Nature 343:746-748

Klomp NI, Schultz MA (2000) Short-tailed shearwaters breeding in Australia forage in Antarctic waters. Mar Ecol Prog Ser 194:307-310

Lima PC, Grantsau R, Lima RCFR, Santos SS (2004) Occurrence and mortality of seabirds along the northern coast of Bahia, and the identification key of the Procellariiformes order and the Stercorariidae family. Atual Ornitol 121: $1-63$

Nel DC, Nel JL, Ryan PG, Klages NTW, Wilson RP, Robertson G (2000) Foraging ecology of grey-headed mollymawks at Marion Island, southern Indian Ocean, in relation to longline fishing activity. Biol Conserv 96:219-231

Neves T, Vooren CM, Bugoni L, Olmos F, Nascimento L (2006a). Distribuição e abundância de aves marinhas no sul do Brasil. In: Neves T, Bugoni L, Rossi-Wongtschowski CLB (eds) Aves oceânicas da região sudeste-sul do Brasil. REVIZEE, São Paulo, p 11-35

Neves TS, Olmos F, Peppes FV, Mohr LV (2006b) National Plan of Action for the Conservation of Albatrosses and Petrels - NPOA-Brazil. IBAMA, Brasília, $124 \mathrm{p}$

Neves TS, Bugoni L, Monteiro DS, Estima SC (2008) Medidas mitigadoras para evitar a captura incidental de aves marinhas em pescarias com espinhéis no Brasil. NEMA/Projeto Albatroz, Rio Grande

Olmos F (1997) Seabirds attending bottom long-line fishing off southeastern Brazil. Ibis 139:685-691

Olmos F, Bugoni L (2006) Agregações de aves marinhas associadas à pesca de espinhel-de-fundo na região sudeste-sul do Brasil. In: Neves T, Bugoni L, Rossi-Wongtschowski CLB (eds) Aves oceânicas da região sudeste-sul do Brasil. REVIZEE, São Paulo, p 69-81

Olson DB, Podestá GP, Evans RH, Brown OB (1988) Temporal variations in the separation of Brazil and Malvinas Currents. Deep-Sea Res 35:1971-1990

Phalan B, Phillips RA, Silk JRD, Afanasyev V and others (2007) Foraging behaviour of four albatross species by night and day. Mar Ecol Prog Ser 340:271-286

Phillips RA, Xavier JC, Croxall JP (2003) Effects of satellite transmitters on albatrosses and petrels. Auk 120: 1082-1090

Phillips RA, Silk JRD, Croxall JP (2005a) Foraging and provisioning strategies of the light-mantled sooty albatross at South Georgia: competition and co-existence with sympatric pelagic predators. Mar Ecol Prog Ser 285:259-270

Phillips RA, Silk JRD, Croxall JP, Afanasyev V, Bennett VJ (2005b) Summer distribution and migration of nonbreeding albatrosses: individual consistencies and implications for conservation. Ecology 86:2386-2396

Phillips RA, Silk JRD, Croxall JP, Afanasyev V (2006) Yearround distribution of white-chinned petrels from South Georgia: relationships with oceanography and fisheries. Biol Conserv 129:336-347

Phillips RA, Croxall JP, Silk JRD, Briggs DR (2007) Foraging ecology of albatrosses and petrels from South Georgia: two decades of insights from tracking technologies. Aquat Conserv 17:S6-S21

Editorial responsibility: Hans Heinrich Janssen, Oldendorf/Luhe, Germany
Pinaud D, Weimerskirch H (2005) Scale-dependent habitat use in a long-ranging central place predator. J Anim Ecol 74:852-863

Pinaud D, Weimerskirch H (2007) At-sea distribution and scale-dependent foraging behaviour of petrels and albatrosses: a comparative study. J Anim Ecol 76:9-19

Ryan PG (1998) The taxonomic and conservation status of the spectacled petrel Procellaria conspicillata. Bird Conserv Int 8:223-235

Ryan PG, Boix-Hinzen C (1998) Tuna longline fisheries off Southern Africa: the need to limit seabird bycatch. S Afr J Sci 94:179-182

Ryan PG, Dorse C, Hilton GM (2006) The conservation status of the spectacled petrel Procellaria conspicillata. Biol Conserv 131:575-583

Seeliger U, Odebrecht C, Castello JP (eds) (1998) Os ecossistemas costeiro e marinho do extremo sul do Brasil. Ecoscientia, Rio Grande

Suryan RM, Dietrich KS, Melvin EF, Balogh GR, Sato F, Ozaki K (2007) Migratory routes of short-tailed albatrosses: use of exclusive economic zones of North Pacific Rim countries and spatial overlap with commercial fisheries in Alaska. Biol Conserv 137:450-460

Terauds A, Gales R, Baker GB, Alderman R (2006) Foraging areas of black-browed and grey-headed albatrosses breeding on Macquarie Island in relation to marine protected areas. Aquat Conserv 16:133-146

Tuck GN, Polacheck T, Bulman CM (2003) Spatio-temporal trends of longline fishing effort in the Southern Ocean and implications for seabird bycatch. Biol Conserv 114:1-27

Warham J (1990) The petrels: their ecology and breeding systems. Academic Press, London

Waugh SM, Weimerskirch H (2003) Environmental heterogeneity and the evolution of foraging behaviour in long ranging greater albatrosses. Oikos 103:374-384

> Weimerskirch H, Guionnet T (2002) Comparative activity pattern during foraging of four albatross species. Ibis 144 : 40-50

> Weimerskirch H, Wilson RP, Lys P (1997) Activity pattern of foraging in the wandering albatross: a marine predator with two modes of prey searching. Mar Ecol Prog Ser 151: $245-254$

> Weimerskirch H, Catard A, Prince PA, Cherel Y, Croxall JP (1999) Foraging White-chinned petrels Procellaria aequinoctialis at risk: from the tropics to Antarctica. Biol Conserv 87:273-275

> Weimerskirch H, Capdeville D, Duhamel G (2000) Factors affecting the number and mortality of seabirds attending trawlers and long-liners in the Kerguelen area. Polar Biol 23:236-249

Wilson RP, Pütz K, Peters G, Culik B, Scolaro JA, Charrassin J, Ropert-Coudert Y (1997) Long-term attachment of transmitting and recording devices to penguins and other seabirds. Wildl Soc Bull 25:101-106

Wood AG, Naef-Daenzer B, Prince PA, Croxall JP (2000) Quantifying habitat use in satellite-tracked pelagic seabirds: application of kernel estimation to albatross locations. J Avian Biol 31:278-286

Submitted: May 26, 2008; Accepted: September 19, 2008 Proofs received from author(s): December 15, 2008 